\title{
KOMPARASI HASIL BELAJAR BAHASA JAWA DI LINGKUNGAN KELUARGA BERBAHASA INDONESIA DENGAN LINGKUNGAN KELUARGA BERBAHASA JAWA SISWA SDN KINCANG 02 KABUPATEN MADIUN TAHUN 2013
}

\author{
Latif Nur Hasan \\ e-mail:ir3ng_mani3zt@yahoo.co.id
}

\begin{abstract}
Student learning outcomes are influenced by several factors, one of which is the family environment factors. Family environment is very supportive of student learning outcomes as well as a large influence on the child's language. The Java language is the mother tongue for the ethnic Javanese. This current uneasy parents when their children can not speak Indonesian or foreign language well, but not restless if not bias the Java language. Most parents use when communicating Indonesian at home. This study aims to determine the differences in learning outcomes in subjects Javanese Indonesian language family environment with a family environment Javanese fifth grade students at Madiun Elementary School District 02 Kincang. This study uses a quantitative approach, and the type of comparative research. The variables of this study is the result of study subjects Javanese Indonesian language students in a family environment and student learning outcomes in the Java language family. The population in this study were all fifth grade students at SDN Kincang 02 Madiun County totaling 42 people. 17 Indonesian -speaking students in a family environment and 25 students in the Java language family. Data collection techniques using structured interview techniques and documentation. Analysis using $t$ test comparison analysis techniques. Based on the data analysis it can be concluded that the results of the Java language learning Indonesian language students in the fifth grade families in Madiun County SDN Kincang 02 with an average of 70.06 categorized well, with a percentage of $52.94 \%$ While the Java language students in the fifth grade families in Madiun County SDN Kincang 02 with an average of 74.8 is categorized well, with a percentage of $40 \%$. So that there are significant differences between the results of study subjects in the Java language Indonesian language family environment and family environment Javanese graders.
\end{abstract}

\begin{abstract}
Abstrak: Hasil belajar siswa dipengaruhi oleh beberapa faktor, salah satunya adalah faktor lingkungan keluarga. Lingkungan keluarga sangat mendukung hasil belajar siswa serta besar pengaruhnya terhadap bahasa anak. Bahasa Jawa merupakan bahasa ibu bagi etnis Jawa. Orangtua saat ini gelisah bila anaknya tidak dapat berbahasa Indonesia atau berbahasa asing dengan baik, tetapi tidak gelisah jika tidak bisa berbahasa Jawa. Kebanyakan orangtua menggunakan bahasa Indonesia bila berkomunikasi di rumah. Penelitian ini bertujuan untuk mengetahui perbedaan hasil belajar mata pelajaran bahasa Jawa di lingkungan keluarga berbahasa Indonesia dengan lingkungan keluarga berbahasa Jawa siswa kelas V di SDN Kincang 02 Kabupaten Madiun. Penelitian ini menggunakan pendekatan kuantitatif, dan jenis penelitian komparasi. Variabel penelitian ini adalah hasil belajar mata pelajaran bahasa Jawa siswa berbahasa Indonesia di lingkungan keluarga dan hasil belajar siswa berbahasa Jawa di lingkungan keluarga. Populasi dalam penelitian ini adalah semua siswa kelas V di SDN Kincang 02 Kabupaten Madiun yang berjumlah 42 orang. 17 siswa berbahasa Indonesia di lingkungan keluarga dan 25 siswa berbahasa Jawa di lingkungan keluarga. Teknik pengumpulan data menggunakan teknik wawancara terstruktur dan dokumentasi. Teknik analisis data menggunakan teknik analisis komparasi tes t. Berdasarkan analisis data dapat disimpulkan bahwa hasil belajar bahasa Jawa siswa berbahasa Indonesia di lingkungan keluarga kelas V di SDN Kincang 02 Kabupaten Madiun dengan rata-rata 70.06 dikategorikan baik, dengan persentase sebesar $52.94 \%$. Sedangkan siswa berbahasa Jawa di lingkungan keluarga kelas V di SDN Kincang 02 Kabupaten Madiun dengan rata-rata 74.8 dikategorikan baik, dengan persentase sebesar $40 \%$. Sehingga terdapat perbedaan yang signifikan antara hasil belajar mata pelajaran bahasa Jawa di lingku-
\end{abstract}


ngan keluarga berbahasa Indonesia dan lingkungan keluarga berbahasa Jawa siswa kelas V di SDN Kincang 02 Kabupaten Madiun Tahun Pelajaran 2012/2013. Hal ini dibuktikan berdasarkan uji $t$ diperoleh $\mathrm{t}_{0}>\mathrm{t}_{\mathrm{t}}$ dimana pada taraf signifikan $5 \%, \mathrm{t}_{0}=3.4422$ dan $\mathrm{t}_{\mathrm{t}}=2.02$.

\section{Kata Kunci: lingkungan keluarga, hasil belajar, bahasa jawa}

Manusia yang merupakan makhluk sosial membutuhkan interaksi dengan manusia lainya. Interaksi tersebut dapat berlangsung secara baik jika tersedia suatu alat atau media. Alat atau media interaksi yang paling utama adalah bahasa. Bahasa merupakan alat komunikasi manusia yang dihasilkan oleh alat ucap. Komunikasi bahasa dapat dilakukan dalam setiap bentuk bahasa, baik bahasa tulis, lisan, isyarat tangan, ungkapan musik dan artistik. Namun, dalam banyak hal, bahasa lisan merupakan bahasa yang paling efektif dan efisien karena kemungkinan terjadinya salah faham sangat kecil.

Variasi bahasa yang digunakan oleh manusia dalam berkomunikasi cukup banyak. Jumlah bahasa yang digunakan di Indonesia pun terbukti hampir sebanding dengan jumlah etnis atau suku bangsa. Setiap suku bangsa memiliki dan menggunakan bahasa daerah yang berbeda suku bangsa yang lain.

Masyarakat Indonesia pada kenyataannya adalah masyarakat dwibahasa karena dalam kesehariannya memiliki dan menggunakan beberapa bahasa. Bahasa pertama: bahasa ibu atau bahasa daerah; bahasa kedua: bahasa Indonesia sebagai bahasa nasional, bahasa resmi, bahasa persatuan. Bahasa ibu anak Indonesia adalah bahasa daerahnya masing-masing. Bahasa Indonesia merupakan bahasa kedua karena anak mempelajarinya setelah anak mempelajari dan menguasai bahasa ibunya. Hal ini akan berbeda jika sejak bayi anak sudah mempelajari bahasa Indonesia, maka bahasa itulah yang menjadi bahasa pertama bagi anak.

Bahasa Jawa merupakan bahasa ibu bagi etnis Jawa. Namun kenyataannya bahasa Jawa sedikit banyak tidak lagi digunakan, apalagi oleh anak-anak, mereka bera- nggapan bahwa bahasa Jawa itu bahasa yang sulit, bahasa yang kuno, mereka lebih mementingkan bahasa Indonesia daripada bahasa Jawa sendiri. Bahasa Jawapun menjadi momok yang menakutkan dipembelajaran anak SD. Bahkan lebih menakutkan daripada pelajaran yang lain. Maka, bias dimungkinkan bahasa Jawa lambat laun akan hilang. Jika bahasa Jawa hilang, sesungguhnya orang Jawa telah kehilangan kebudayaannya yang merupakan jati diri serta kepribadian warisan nenek moyang.

Salah satu upaya supaya bahasa Jawa tidak hilang, salah satu caranya adalah tetap menggunakan bahasa Jawa di setiap hubungan sosial dalam etnis Jawa. Pembiasaan ini dalam artian berbicara menggunakan bahasa Jawa baik dari segi bahasanya maupun unggah-ungguh. Anak SD merupakan peniru yang baik. Supaya dapat ditiru oleh anakanak, bahasa Jawa sebaiknya digunakan pula oleh kedua orang tua dan anggota keluarga. Belajar bahasa Jawa tidak hanya dilakukan secara formal (sekolah) saja melainkan juga secara informal (masyarakat). Secara formal bahasa Jawa dipelajari siswa di sekolah-sekolah dalam pembelajaran. Secara informal bahasa Jawa bisa diajarkan kepada anak-anak di lingkungan keluarga atau masyarakat, sebagai bentuk praktik dari yang telah dipelajari di sekolah.

Berdasar wawancara dan observasi yang telah dilakukan terhadap salah satu guru di SDN Kincang 02 Kabupaten Madiun menunjukkan bahwa sebagian hasil belajar bahasa Jawa di kelas V masih kurang dari KKM, padahal pembelajaran yang dilakukan sudah dirasa sudah menyenangkan. Bahasa Jawa di sekolah hanya dipelajari bukan diterapkan dalam sekolah. Bahasa Jawa hanya digunakan jika pada pelajaran bahasa Jawa saat itu. Setelah itu mereka berkomu- 
nikasi dengan guru memakai bahasa Indonesia. Sebagian anak dalam keluarganya dibiasakan memakai bahasa Indonesia, jadi mereka belum terbiasa memakai bahasa Jawa dalam kehidupan sehari-hari.

Berdasarkan latar belakang masalah tersebut maka rumusan masalah dalam penelitian ini adalah "Berapa persentase tingkat hasil belajar mata pelajaran bahasa Jawa yang berada di lingkungan keluarga berbahasa Indonesia dan di lingkungan keluarga berbahasa Jawa siswa kelas V di SDN Kincang 02 Kabupaten Madiun tahun pelajaran 2012/2013. Serta adakah perbedaan antara hasil belajar mata pelajaran bahasa Jawa di lingkungan keluarga berbahasa Indonesia dengan lingkungan keluarga berbahasa Jawa siswa kelas V di SDN Kincang $02 \mathrm{Ka}-$ bupaten Madiun tahun pelajaran 2012/2013."

\section{Metode Penelitian}

Penelitian ini didahului dengan mencari data-data yang dibutuhkan dalam penelitian dan menentukan siapa saja yang dapat dijadikan sumber utama dalam penelitian ini, sehingga data yang diperoleh benarbenar terpercaya. Selanjutnya mencari datadata khusus yaitu data mengenai komparasi lingkungan keluarga berbahasa Indonesia dan lingkungan keluarga berbahasa Jawa terhadap hasil belajar bahasa Jawa, untuk itu pertama-tama yang dilakukan oleh peneliti adalah wawancara terstruktur pada siswa kelas $\mathrm{V}$ untuk mengelompokkan data siswa mana yang memakai bahasa Indonesia di lingkungan keluarga dan yang memakai bahasa Jawa di lingkungan keluarga, selanjutnya meminta nilai ulangan tengah semester bahasa Jawa kelas V semester genap tahun pelajaran 2012/2013 kepada guru pelajaran bahasa Jawa kelas V.

Setelah data terkumpul yang dilakukan adalah mengolah data, dimulai dari mengelompokkan, mencatat, dan pengujian.
Mengelompokkan, yaitu mengelompokkan data-data siswa yang memakai bahasa Indonesia di lingkungan keluarga dan siswa yang memakai bahasa Jawa di lingkungan keluarga. Mencatat, yaitu mencatat kembali hasil belajar bahasa Jawa kelas. Pengujian, yaitu menguji data tersebut dengan rumus analisis komparasi tes $\mathrm{t}$ untuk mengetahui ada tidaknya perbedaan lingkungan keluarga berbahasa Indonesia dan lingkungan keluarga berbahasa Jawa terhadap hasil belajar bahasa Jawa kelas V di SDN Kincang 02 Kabupaten Madiun. Adapun rumus yang digunakan adalah:

$$
\mathrm{t}_{0}=\frac{\mathrm{M}_{1}-\mathrm{M}_{2}}{\mathrm{SE}_{\mathrm{M}_{1-} \mathrm{M}_{2}}}
$$

Setelah data teruji dengan tes t kemudian diperoleh hasil $t_{0}$ ( $t$ observasi) selanjutnya dibandingkan dengan $t$ tabel maka dapat diketahui hasilnya sehingga dapat disimpulkan dengan memakai ketentuanketentuan: (1) Jika $t_{0} \geq t_{t}$ maka Ho ditolak atau Ha diterima berarti perbedaan mean dari kedua sampel itu adalah perbedaan yang signifikan. (2) Jika $t_{0}<t_{t}$ maka Ho diterima dan Ha ditolak berarti tidak ada perbedaan mean dua sampel tersebut. Berarti pula perbedaan mean dua sampel itu bukanlah perbedaan mean yang signifikan melainkan perbedan yang terjadi hanya secara kebetulan saja sebagai akibat sampling eror (Widyaningrum, 2011:154)

Populasi dalam penelitian ini adalah siswa kelas V SDN Kincang 02 Kabupaten Madiun yang berjumlah 42 orang. Maka dalam penelitian ini, peneliti menggunakan semua populasi untuk diteliti yang disebut dengan sampel jenuh. Dengan demikian, penelitian ini dapat disebut penelitian populasi.

Teknik pengumpulan data dalam penelitian ini menggunakan wawancara terstruktur dan dokumentasi. Wawancara terstruktur disusun secara terperinci sehingga menyerupai check-list. Peneliti hanya membubuhkan tanda $\sqrt{ }$ (check) pada nomor yang 
sesuai. Wawancara ini digunakan untuk mendapatkan data tentang siswa mana yang berbahasa Indonesia dan berbahasa Jawa di lingkungan keluarga. Dokumentasi merupakan teknik pengumpulan data yang ditujukan kepada subyek penelitian. Sehingga metode ini dipergunakan untuk memperoleh data nilai ulangan tengah semester bahasa Jawa siswa kelas $\mathrm{V}$, serta keadaan guru dan siswa/siswi SDN Kincang 02 Kabupaten Madiun.

\section{PEMBAHASAN}

\section{Lingkungan Keluarga}

Lingkungan adalah segala hal yang mempengaruhi individu, sehingga individu itu terlibat/terpengaruh karenanya. Semenjak masa konsepsi dan masa-masa selanjutnya, perkembangan individu dipengaruhi oleh mutu makanan yang diterimanya, temperatur udara sekitarnya, suasana dalam keluarga, sikap-sikap orang sekitar, hubungan dengan sekitarnya, suasana pendidikan (informal, formal, nonformal) (L.N., 2009: 2009:175).

Keluarga merupakan unit sosial terkecil yang memiliki peranan penting dan menjadi dasar bagi perkembangan psikososial anak dalam konteks sosial yang lebih luas (Desmita: 219). Fungsi dasar keluarga adalah memberikan rasa memiliki, rasa aman, rasa kasih sayang, dan mengembangkan hubungan yang baik antara anggota keluarga. Hubungan cinta kasih dalam keluarga tidak sebatas perasaan, akan tetapi juga menyangkut pemeliharaan, rasa tanggung jawab, perhatian, pemahaman, respek dan keinginan untuk menumbuhkembangkan anak yang dicintainya (L.N.,2009: 38). Menurunnya perhatian, bimbingan dan kasih sayang orangtua diduga keras menjadi penyebab merosotnya prestasi pendidikan anak usia sekolah dan meningkatnya kasus kenakalan remaja yang sudah menjurus ke arah brutalitas serta sadis di kota-kota besar.

\section{Hakikat Bahasa}

Mata Pelajaran Bahasa Jawa merupakan kurikulum muatan lokal bagi SD dan SMP sederajat sesuai dengan Keputusan Gubernur Jawa Timur Nomor 188/188/KPTS/013/2005 tentang kurikulum bahasa Jawa yang wajib dilaksanakan untuk jenjang SD dan SMP atau yang sederajat di seluruh wilayah Jawa Timur.

Faktor lingkungan besar pengaruhnya terhadap perkembangan bahasa seseorang yaitu besarnya kesempatan yang diperoleh dari lingkungannya. Individu yang sehariharinya banyak berinteraksi dengan lingkungan yang kaya kemampuan bahasanya cenderung memiliki kesempatan lebih banyak dan lebih bagus untuk mengembangkan bahasanya. Sebaliknya, individu yang banyak berinteraksi dengan lingkungan yang miskin kemampuan bahasanya cenderung memberikan kesempatan yang terbatas terhadap perkembangan bahasa individu yang tumbuh dan berkembang di dalamnya (Ali, 2009:128).

Sedangkan menurut Ali dan Asrori, secara rinci dapat diidentifikasikan sejumlah faktor yang mempengaruhi perkembangan bahasa, yaitu: (1) Kognisi; tinggi rendahnya kemampuan kognisi individu akan mempengaruhi cepat lambatnya perkembangan bahasa individu, (2) Pola Komunikasi dalam Keluarga; dalam suatu keluarga yang pola komunikasinya banyak arah atau interaksinya relatif demokratis akan mempercepat perkembangan bahasa anggota keluarganya dibanding yang menerapkan pola komunikasi dan interaksi sebaliknya, (3) Jumlah Anak atau Anggota Keluarga; suatu keluarga yang memiliki banyak anak atau banyak anggota keluarga, perkembangan bahasa anak lebih cepat, karena terjadi komunikasi yang bervariasi dibandingkan keluar- 
ga yang hanya memiliki anak tunggal dan tidak ada anggota keluarga lain selain keluarga inti, (4) Posisi Urutan Kelahiran; Perkembangan bahasa anak yang posisi urutan kelahirannya di tengah akan lebih cepat ketimbang anak sulung atau anak bungsu. Hal ini disebabkan anak tengah memiliki arah komunikasi ke atas maupun ke bawah. Adapun anak sulung hanya memiliki arah komunikasi ke bawah saja dan anak bungsu hanya memiliki arah komunikasi ke atas saja, (5) Kedwibahasaan; anak yang dibesarkan dalam keluarga yang menggunakan bahasa lebih dari satu akan lebih bagus dan lebih cepat perkembangan bahasanya ketimbang yang hanya menggunakan satu bahasa saja karena anak terbiasa menggunakan bahasa secara bervariasi. Misalnya, di dalam rumah dia menggunakan bahasa Sunda dan di luar rumah dia menggunakan bahasa Indonesia (2009:128-129).

\section{Hasil Belajar}

Hasil belajar adalah kemampuan yang diperoleh anak setelah mengikuti kegiatan belajar. Belajar itu sendiri merupakan suatu proses dari seseorang yang berusaha untuk memperoleh suatu bentuk perubahan perilaku yang relatif menetap. Dalam kegiatan belajar yang terprogram dan terkontrol yang disebut kegiatan pembelajaran/kegiatan instruksional, tujuan belajar telah ditetapkan lebih dahulu oleh guru. Anak yang berhasil dalam belajar ialah yang berhasil mencapai tujuan-tujuan pembelajaran atau tujuantujuan instruksional (Abdurrahman:37-38).

Menurut para ahli pendidikan, hasil belajar yang dicapai oleh peserta didik dipengaruhi oleh dua faktor utama, yakni faktor yang terdapat di dalam diri peserta didik itu sendiri yang disebut dengan factor internal dan faktor yang terdapat di luar diri peserta didik yang disebut dengan eksternal (Hallen, 2002:130). Faktor internal atau faktor yang terdapat di dalam diri peserta didik itu sendiri antara lain kurangnya kemampuan dasar yang dimiliki oleh peserta didik, kurangnya bakat khusus suatu situasi belajar tertentu, kurangnya motivasi atau dorongan untuk belajar, situasi pribadi terutama emosional yang dihadapi peserta didik pada waktu tertentu dapat menimbulkan kesulitan dalam belajar, factor jamaniah yang tidak mendukung kegiatan belajar, faktor hereditas (bawaan) yang tidak mendukung kegiatan belajar. Adapun factor yang terdapat di luar diri peserta didik (faktor eksteren) yang dapat mempengaruhi hasil belajar siswa ialah faktor lingkungan sekolah yang kurang memadai bagi situasi belajar peserta didik, situasi dalam keluarga mendukung situasi belajar peserta didik, situasi lingkungan sosial yang mengganggu kegiatan belajar siswa.

\section{Hubungan antara Lingkungan Keluarga dengan Perkembangan Bahasa dan Hasil Belajar Siswa}

Menurut Yusuf dalam Djamarah, hubungan yang sehat antara orang tua dengan anak (penuh perhatian dan kasih saying dari orang tuanya) memberikan pengaruh yang besar terhadap kemampuan berbahasa anak. Sebaliknya, hubungan yang kurang baik antara orang tua dan anak menjadi penghalang terwujudnya komunikasi yang baik. Sikap kasar orang tua, sering memarahi anak, kurang memberikan kasih sayang, kurang perhatian untuk memberikan perhatian atau contoh berbahasa yang baik kepada anak, bisa menjadi penyebab kurang berkembangnya kemampuan berbahasa anak (Djamarah: 76).

Lingkungan sosial yang lebih banyak mempengaruhi kegiatan belajar mengajar ialah orang tua dan keluarga siswa itu sendiri. Sifat-sifat orang tua, praktik pengelolaan keluarga, ketegangan keluarga, dan demografi keluarga (letak rumah) semuanya dapat memberikan dampak baik maupun 
buruk terhadap kegiatan belajar dan hasil yang dicapai siswa (Syah,2008:138).

\section{Hasil Analisis Data}

Berdasarkan data hasil belajar bahasa Jawa kelas V di SDN Kincang 02 Kabupaten Madiun, untuk mengetahui hasil analisisnya dimasukkan dalam tabel sebagai berikut:

Tabel. 1 Perhitungan Standar Deviasi Hasil Belajar Mata Pelajaran Bahasa Jawa Siswa Berbahasa Indonesia di Lingkungan Keluarga

\begin{tabular}{|c|c|c|c|c|c|c|}
\hline $\mathbf{X}_{\mathbf{1}}$ & $\mathbf{F}$ & $\mathbf{f \mathbf { X } _ { \mathbf { 1 } }}$ & $\mathbf{x}^{\prime}$ & $\mathbf{f x}^{\mathbf{\prime}}$ & $\mathbf{X}^{\mathbf{2}}$ & $\mathbf{f x}^{\mathbf{2}}$ \\
\hline 95 & 1 & 95 & 6 & 6 & 36 & 36 \\
\hline 92 & 1 & 92 & 5 & 5 & 25 & 25 \\
\hline 90 & 1 & 90 & 4 & 4 & 16 & 16 \\
\hline 82 & 1 & 82 & 3 & 3 & 9 & 9 \\
\hline 77 & 2 & 154 & 2 & 4 & 4 & 8 \\
\hline 76 & 2 & 152 & 1 & 2 & 1 & 2 \\
\hline 74 & 1 & 74 & 0 & 0 & 0 & 0 \\
\hline 71 & 1 & 71 & -1 & -1 & 1 & 1 \\
\hline 64 & 3 & 192 & -2 & -6 & 4 & 12 \\
\hline 62 & 1 & 62 & -3 & -3 & 9 & 9 \\
\hline 50 & 1 & 50 & -4 & -4 & 16 & 16 \\
\hline 42 & 1 & 42 & -5 & -5 & 25 & 25 \\
\hline 35 & 1 & 35 & -6 & -6 & 36 & 36 \\
\hline $\mathbf{N}$ & $\mathbf{1 7}$ & $\mathbf{1 1 9 1}$ & - & $-\mathbf{1}$ & $\mathbf{1 8 2}$ & $\mathbf{1 9 5}$ \\
\hline
\end{tabular}

Dari hasil perhitungan di atas, dapat diketahui $\mathrm{M}_{1}$ adalah 70.06 dan $\mathrm{SD}_{1}$ adalah 3.3863 untuk menentukan kategori nilai hasil belajar mata pelajaran bahasa Jawa siswa kelas V di SDN Kincang 02 Kabupaten Madiun itu baik, cukup dan kurang, dibuat pengelompokan skor dengan menggunakan rumus: (1) Skor lebih dari $\mathrm{M}_{1}+$ 1. $\mathrm{SD}_{1}$ adalah kategori hasil belajar baik (2) Skor kurang dari $\mathrm{M}_{1}-1 . \mathrm{SD}_{1}$ adalah kategori hasil belajar kurang (3) Skor antara $\mathrm{M}_{1}+$ 1. $\mathrm{SD}_{1}$ dan $\mathrm{M}_{1}-1 . \mathrm{SD}_{1}$ adalah kategori hasil belajar cukup (Sudjiono, 2009:176).

Untuk mengetahui lebih jelas tentang persentase hasil belajar bahasa Jawa siswa berbahasa Indonesia di lingkungan keluarga kelas V di SDN Kincang 02 Kabupaten Madiun dapat dilihat dalam tabel berikut:

Tabel. 2 Kategorisasi Hasil Belajar Mata Pelajaran Bahasa Jawa Siswa Berbahasa Indonesia di Lingkungan Keluarga

\begin{tabular}{|c|c|c|c|c|}
\hline No. & Skor & Frekuensi & Prosentase & Kategori \\
\hline 1. & $74-100$ & 9 & $52.94 \%$ & Baik \\
\hline 2. & $67-73$ & 1 & $5.88 \%$ & Cukup \\
\hline 3. & $0-66$ & 7 & $41.18 \%$ & Kurang \\
\hline \multicolumn{2}{|r|}{ Jumlah } & 17 & $100 \%$ & \\
\hline
\end{tabular}

Dari pengkategorian tersebut dapat diketahui, bahwa yang menyatakan hasil belajar mata pelajaran bahasa Jawa siswa yang berbahasa Indonesia kelas $\mathrm{V}$ SDN Kincang 02 Kabupaten Madiun dalam kategori baik dengan frekuensi sebanyak 9 responden $(52.94 \%)$, kategori cukup 1 responden $(5.88 \%)$, dan kategori kurang 7 responden $(41.18 \%)$.

Berdasarkan data hasil belajar bahasa Jawa kelas V di SDN Kincang 02 Kabupaten Madiun, untuk mengetahui hasil analisisnya dimasukkan dalam tabel sebagai berikut:

Tabel. 3 Perhitungan Standar Deviasi Hasil Belajar Mata Pelajaran Bahasa Jawa Siswa Berbahasa Jawa di Lingkungan Keluarga

\begin{tabular}{|c|c|c|c|c|c|c|}
\hline $\mathbf{X}_{\mathbf{2}}$ & $\mathbf{F}$ & $\mathbf{f X}_{\mathbf{2}}$ & $\mathbf{x}^{\prime}$ & $\mathbf{f x}^{\prime}$ & $\mathbf{x}^{\mathbf{2}}$ & $\mathbf{f x}^{\mathbf{2}}$ \\
\hline 96 & 1 & 96 & 9 & 9 & 81 & 81 \\
\hline 92 & 2 & 184 & 8 & 16 & 64 & 128 \\
\hline 90 & 1 & 90 & 7 & 7 & 49 & 49 \\
\hline 88 & 2 & 176 & 6 & 12 & 36 & 72 \\
\hline 86 & 1 & 86 & 5 & 5 & 25 & 25 \\
\hline 83 & 1 & 83 & 4 & 4 & 16 & 16 \\
\hline 82 & 2 & 164 & 3 & 6 & 9 & 18 \\
\hline 80 & 1 & 80 & 2 & 2 & 4 & 4 \\
\hline 79 & 1 & 79 & 1 & 1 & 1 & 1 \\
\hline 77 & 1 & 77 & 0 & 0 & 0 & 0 \\
\hline 75 & 2 & 150 & -1 & -2 & 1 & 2 \\
\hline 74 & 1 & 74 & -2 & -2 & 4 & 4 \\
\hline 70 & 2 & 140 & -3 & -6 & 9 & 18 \\
\hline 68 & 1 & 68 & -4 & -4 & 16 & 16 \\
\hline 65 & 1 & 65 & -5 & -5 & 25 & 25 \\
\hline
\end{tabular}




\begin{tabular}{|c|c|c|c|c|c|c|}
\cline { 3 - 6 } 63 & 1 & 63 & -6 & -6 & 36 & 36 \\
\hline 50 & 3 & 150 & -7 & -21 & 49 & 147 \\
\hline 45 & 1 & 45 & -8 & -8 & 64 & 64 \\
\hline $\mathbf{N}$ & $\mathbf{2 5}$ & $\mathbf{1 8 7 0}$ & - & $\mathbf{8}$ & $\mathbf{4 8 9}$ & $\mathbf{7 0 6}$ \\
\hline
\end{tabular}

Dari hasil perhitungan di atas, dapat diketahui $\mathrm{M}_{1}$ adalah 74.8 dan $\mathrm{SD}_{1}$ adalah 5.3195. Untuk menentukan kategori nilai hasil belajar mata pelajaran bahasa Jawa siswa kelas V di SDN Kincang 02 Kabupaten Madiun itu baik, cukup dan kurang perhitungannya sama dengan yang sebelumnya.

Untuk mengetahui lebih jelas tentang persentase hasil belajar mata pelajaran bahasa Jawa siswa berbahasa Jawa di lingkungan keluarga kelas V di SDN Kincang 02 Kabupaten Madiun dapat dilihat dalam tabel berikut:

Tabel 4 Kategorisasi Hasil Belajar Mata Pelajaran Bahasa Jawa Siswa Berbahasa Jawa di Lingkungan Keluarga

\begin{tabular}{|c|c|c|c|c|}
\hline No. & Skor & Frekuensi & Prosentase & Kategori \\
\hline 1. & $81-100$ & 10 & $40 \%$ & Baik \\
\hline 2. & $69-80$ & 8 & $32 \%$ & Cukup \\
\hline 3. & $45-68$ & 7 & $28 \%$ & Kurang \\
\hline \multicolumn{2}{|c|}{ Jumlah } & 25 & $100 \%$ & \\
\hline
\end{tabular}

Dari pengkategorian tersebut dapat diketahui, bahwa yang menyatakan hasil belajar mata pelajaran bahasa Jawa siswa berbahasa Jawa kelas V di SDN Kincang 02 Kabupaten Madiun dalam kategori baik dengan frekuensi sebanyak 10 responden (40 $\%)$, kategori cukup 8 responden (32\%), dan kategori kurang 7 reponden $(28 \%)$.

Dari perhitungan siswa yang berbahasa Indonesia di lingkungan keluarga dan siswa yang berbahasa Jawa di lingkungan keluarga dimasukkan dalam rumus:

$$
\begin{gathered}
S E_{M_{1}}=\frac{S D_{1}}{\sqrt{n_{1}-1}}=\frac{3.3863}{\sqrt{17-1}}=\frac{3.3863}{\sqrt{16}} \\
=\frac{3.3863}{4}=0.8466
\end{gathered}
$$

$$
\begin{gathered}
S E_{M_{2}}=\frac{S D_{2}}{\sqrt{n_{1}-1}}=\frac{5.3195}{\sqrt{25-1}}=\frac{5.3195}{\sqrt{24}} \\
=\frac{5.3195}{4.8989}=1.0858 \\
\mathrm{SE}_{\mathrm{M}_{1}-\mathrm{M}_{2}=\sqrt{\mathrm{SE}_{\mathrm{M}_{1}}{ }^{2}+\mathrm{SE}_{\mathrm{M}_{2}}{ }^{2}}=1.3768} \\
\mathrm{t}_{0}=\frac{\mathrm{M}_{1}-\mathrm{M}_{2}}{\mathrm{SE}_{\mathrm{M}_{1-} \mathrm{M}_{2}}}=\frac{70.06-78.4}{1.3768}=\frac{-4.74}{1.3768} \\
=-3.4427
\end{gathered}
$$

(tanda minus di sini bukan tanda aljabar, karena $t_{0}$ di sini merupakan ada selisih derajat perbedaan nilai antar variabel sebesar nilai minus tersebut, sehingga tanda minus tersebut tidak perlu dibandingkan).

\section{Interpretasi}

Untuk menjawab hipotesis yang telah diteliti apakah ada perbedaan yang signifikan antara hasil belajar mata pelajaran bahasa Jawa siswa kelas V yang berbahasa Indonesia di lingkungan keluarga dan yang berbahasa Jawa di lingkungan keluarga SDN Kincang 02 Kabupaten Madiun, maka selanjutnya dengan melakukan pembuktian dari hipotesis terhadap data dan interpretasi.

Interpretasi yang menghasilkan hasil dengan $t_{t}($ tabel $t)$. Jika $t_{0}(t$ obeservasi) lebih besar dari $t_{t}$ maka Ho ditolak dan Ha diterima, jika $t_{0}$ lebih kecil dari $t_{t}$ maka Ho diterima dan Ha ditolak. Jika perbedaan itu ada apakah perbedaan itu merupakan yang berarti atau signifikan ataukah bahwa perbedaan hanyalah kebetulan saja.

Sebelum dibandingkan dengan nilai " $\mathrm{t}$ " kita menggunakan rumus:

$\mathrm{db}=\left(\mathrm{n}_{1}+\mathrm{n}_{2}\right)-2=(25+17)-2=42-2=40$

Dengan melihat $d b=40$ pada $t_{t}$ (tabel $\mathrm{t})$, maka hasil $\mathrm{t}_{0}$ dibandingkan dengan $\mathrm{t}_{\mathrm{t}}$ yaitu 2.02. Pada taraf signifikan $5 \%, \mathrm{t}_{0}=3.44$ 27 dan $t_{t}=2.02\left(t_{0}>t_{t}\right)$, karena $t_{0}$ lebih besar dari t $t_{\mathrm{t}}$ maka Ho ditolak dan Ha diterima. 
Berdasarkan uraian tersebut berarti terdapat perbedaan yang signifikan antara hasil belajar mata pelajaran bahasa Jawa di lingkungan keluarga berbahasa Indonesia dengan lingkungan keluarga berbahasa Jawa siswa kelas V di SDN Kincang $02 \mathrm{Ka}-$ bupaten Madiun Tahun Pelajaran 2012/2013. Dari segi rata-rata masing-masing variabel sudah terlihat jika rata-rata hasil belajar bahasa Jawa siswa yang berbahasa Indonesia dalam lingkungan keluarga adalah 70.06 dan siswa yang berbahasa Jawa di lingkungan keluarga adalah 74.8 , jadi rata-rata hasil belajar bahasa Jawa siswa yang berbahasa Indonesia di lingkungan keluarga lebih rendah dibandingkan dengan rata-rata hasil belajar bahasa Jawa siswa yang berbahasa Jawa di lingkungan keluarga.

\section{KESIMPULAN}

Berdasarkan deskripsi data dan analisis data dalam penelitian ini dapat diambil kesimpulan bahwa: (1) Hasil belajar bahasa Jawa siswa yang berbahasa Indonesia dilingkungan keluarga kelas V di SDN Kincang 02 Kabupaten Madiun Tahun Pelajaran 2012/2013 dengan rata-rata 70.06 dalam kategori baik dengan frekuensi sebanyak 9 responden $(52.94 \%)$, kategori cukup 1 responden $(5.88 \%)$, dan kategori kurang 7 responden $(41.18 \%)$. Dengan demikian dapat dikatakan bahwa hasil belajar bahasa Jawa siswa yang berbahasa Indonesia di lingkungan keluarga kelas V di SDN Kincang 02 Kabupaten Madiun dikategorikan baik. (2) Hasil belajar bahasa Jawa siswa yang berbahasa Jawa di lingkungan keluarga kelas $\mathrm{V}$ SDN Kincang 02 Kabupaten Madiun dengan rata-rata 74.8 dalam kategori baik dengan frekuensi sebanyak 10 responden (40\%), kategori cukup 8 responden (32\%), dan kategori kurang 7 reponden (28\%). Dengan demikian dapat dikatakan bahwa hasil belajar bahasa Jawa siswa yang berbahasa Jawa di lingkungan keluarga kelas $\mathrm{V}$ di SDN
Kincang 02 Kabupaten Madiun dikategorikan baik. (3) Terdapat perbedaan yang signifikan antara hasil belajar mata pelajaran bahasa Jawa di lingkungan keluarga berbahasa Indonesia dengan lingkungan keluarga berbahasa Jawa siswa kelas V di SDN Kincang 02 Kabupaten Madiun Tahun Pelajaran 2012/2013. Berdasarkan uji t diperoleh $\mathrm{t}_{0}>\mathrm{t}_{\mathrm{t}}$ di mana pada taraf signifikan $5 \%, \mathrm{t}_{0}=$ 3.4427 dan $t_{t}=2.02$.

\section{DAFTAR PUSTAKA}

A, Hallen. Bimbingan dan Konseling dalam Islam. Jakarta: Ciputat Pers. 2002.

Abdurrahman, Mulyono. Pendidikan Anak Berkesulitan Belajar. Jakarta: Rineka Cipta. 2003.

Ali, Mohammad dan Mohammad Asrori. Psikologi Remaja Perkembangan Peserta Didik. Jakarta: Bumi Aksara. 2009.

Arikunto, Suharsimi. Prosedur Penelitian Suatu Pendekatan Praktek, Jakarta: PT. Rineka Cipta. 2002.

Desmita. Psikologi Perkembangan Peserta Didik. Bandung: PT Remaja Rosdakarya.

Djamarah, Syaiful Bahri. Psikologi Belajar. Jakarta: Rineka Cipta. 2008.

L.N., Syamsu Yusuf. Psikologi Perkembangan Anak dan Remaja. Bandung: PT Remaja Rosdakarya. 2009.

L.N., Syamsu Yusuf dan Achmad Juntika Nurihsan. Landasan Bimbingan dan Konseling. Bandung: PT Remaja Rosdakarya. 2009.

Margono. Metodologi Penelitian PendidiPkan. Jakarta: PT Rineka Cipta. 1997.

Sudijono, Anas. Pengantar Statistik Pendidikan. Jakarta: Raja Grafindo Persada. 2009.

Sugiyono. Metode Penelitian Pendidikan. Pendekatan Kuantitatif, Kualitataf dan R\&D. Bandung: Alfabeta. 2006. 
9 Jurnal Pemikiran dan Pengembangan SD, Jilid 1, Nomor 2, September 2013, hlm. 1-9

Sukandarrumidi. Metodologi Penelitian. Widyaningrum, Retno. Statistika. YogyaYogyakarta: Gadjah mada University karta: Pustaka Felicha. 2011. Press. 2006.

Syah, Muhibbin. Psikologi Pendidikan dengan Pendekatan Baru. Bandung: PT Remaja Rosdakarya. 2008.

Tubiyono. Kebijakan Pemerintah Daerah tentang Pemakaian Bahasa Lokal: Studi Kasus Pemerintah Kota Surabaya pada Era Otoda. (online), diakses 4 April 2013. http://.tubiyono.com/template-features/tulisan-ilmiah/makalah/ 92-kebijakan-pemerintah-daerah-tentangpemakaian-bahasa-lokal-studikasus-pemerintah-kota-surabaya-pada-era-otoda, diakses 4 April 2013. 